\title{
Restoratívne prvky v správnom trestaní ${ }^{1}$
}

Tomaš, L.*

TOMAŠ, L.: Restoratívne prvky v správnom trestaní. Právny obzor, 104, 2021, č. 2, s. 155 -169 .

Restorative elements in administrative punishment. The Slovak legal regulation of administrative punishment is in many respects interspersed. The means of applying elements of restorative justice are no exception. The normative diction of the law on misdemeanors, or even another regulation, hardly thinks about them. In the scientific literature to date, there have been several inspiring considerations about the possibilities of modifying this state within the processes of creating the future sanction law of public administration. However, it is not possible to limit the formulation of impulses in the de lege ferenda level, especially in the legal-application context. Administrative authorities apply the applicable law in the process of hearing administrative offenses. Attention should therefore be paid to methods of strengthening the restorative element in administrative punishment in the light of an effective normative platform. The examination of these aspects is the subject of a translated article. The author focuses on whether the categories of the general theory of law (interpretation, the legal imperative of analogy, subsidiarity of legislation) can create space for strengthening the restorative element in administrative punishment. He examines the above, especially in the light of the possibilities of concluding a settlement on a proper tort.

Key words: restorative justice, administrative punishment, analogy, interpretation, subsidiarity

\section{I Úvod}

Otázkam restoratívnej (obnovujúcej) justície sa v ostatných desat'ročiach dostáva značnej právnonormatívnej, právnovedeckej i právnoaplikačnej pozornosti. Účelom restoratívnych prístupov je snaha o (i) individualizáciu trestného postihu, (ii) dosiahnutie pozitívnej motivácie páchatel’a trestného činu k životu v súlade so zákonom, ako aj (iii) zapojenie osôb poškodených trestnou činnost'ou do riešenia trestných vecí. ${ }^{2}$ Restoratívna justícia je vo všeobecnosti považovaná za proces, do ktorého sú v dôsledku spáchania trestného činu a nezriedka i spôsobenia škody zapojené viaceré strany. Táto justícia je budovaná na myšlienke existencie spravodlivosti, v ktorej sú zastúpené prvky zdôrazňujúce práva poškodených subjektov. ${ }^{3}$

Najvýznamnejšie prejavy restoratívnej spravodlivosti predstavujú (i) vytvorenie podmienok na široké uplatnenie alternatívnych spôsobov konaní pred súdom a (ii) využitie

* JUDr. Lukáš T o m a š, Ústav teórie práva Gustava Radbrucha, Právnická fakulta, Univerzita Pavla Jozefa Šafárika v Košiciach.

${ }^{1}$ Článok predstavuje výstup z projektu VEGA č. 1/0386/19 s názvom Nové dimenzie metodológie právnej argumentácie - Úloha právnych princípov vo viacúrovňovom právnom systéme.

${ }^{2}$ Porovnaj ROMŽA, S. Konkurencia procesných alternatív. In STRÉMY, T. (ed.) Restorativna justicia a systém alternativnych trestov. Zborník príspevkov z medzinárodnej vedeckej konferencie. Trnava : Leges, 2017, s. 118.

${ }^{3}$ MICHAL'OV, L. Podmienky ukladania alternatívnych trestov z pohl'adu de lege ferenda. In ROMŽA, S. - FERENČÍKOVÁ, S. - MICHALOV, L. (eds.) IV. Košické dni trestného práva. Privatizácia výkonu trestu odňatia slobody, sci-fi alebo jediná možnost? Zborník vedeckých prác. Košice : Univerzita Pavla Jozefa Šafárika v Košiciach, 2020, s. 293. 
alternatív na potrestanie $\mathrm{v}$ trestných veciach. ${ }^{4}$ Toto konštatovanie platí predovšetkým a takmer výlučne pre oblast' trestnoprávnej regulácie. V odbore administratívneho trestania je normatívne zakotvenie a $\mathrm{v}$ nadväznosti na to aj realizačné presadzovanie restoratívnych východísk de lege lata nedostatočné.

Ak chceme posilnit' presadzovanie restoratívneho prvku v správnom trestaní de lege lata, nemožno sa obmedzit' na formulovanie návrhov de lege ferenda. ${ }^{5}$ Treba uvažovat' o možnostiach, ktoré vytvoria legálny priestor na aplikáciu restoratívnych zásad aj pri nečinnosti zákonodarcu. Inak povedané, pri nedostatku úpravy restoratívnych inštitútov $\mathrm{v}$ administratívnom práve je potrebné hl'adat' metodologické bázy alternatívnych možností (ciest, odôvodnení) aplikácie alternatívnych (restoratívnych) spôsobov riešenia administratívnych trestných vecí.

Pravdou je, že alternatívne možnosti presadzovania restoratívnych princípov nedoznajú stupeň precíznosti a prepracovanosti, aký by sa dosiahol legislatívnou cestou. Avizovaná skutočnost' však nemôže vytvorit' priestor na odmietnutie snahy o posilnenie uplatňovania restoratívnych princípov v správnom konaní. Platí to tým skôr, že úprava slovenského správneho práva trestného je dlhodobo hodnotená ${ }^{~}$ ako nedostatočná, čoho aktuálnym a markantným výrazom je napríklad sporne ponímaná nepriama novelizácia ${ }^{7}$ relevantných ustanovení osobitných administratívnych predpisov požadujúca aplikáciu základných zásad trestného konania v kontexte právno-realizačných postupov pri správnom trestaní [§ 195 písm. c) Správneho súdneho poriadku]. ${ }^{8}$

Otázkou (predmetom výskumu objektivizovaného v príspevku) je, akými cestami možno nedostatok právneho zakotvenia restoratívnych koncepcií v sankčnom práve verejnej správy konvalidovat'.

${ }^{4}$ ROMŽA, S. Aktívna účast' poškodeného na procesných úkonoch prípravného konania ako prostriedok efektívneho uplatňovania jednotlivých foriem restoratívnej justície. In STRÉMY, T. (ed.) Restoratívna justicia a alternativne tresty v aplikačnej praxi. Zborník z medzinárodnej vedeckej konferencie. Trnava : Leges, 2015, s. 163 .

${ }^{5}$ De lege ferenda o presadzovaní restoratívnych prvkov v správnom trestaní JAKAB, R. Uplatnenie restoratívnych prístupov v konaní o priestupku. In ROMŽA, S. - FERENČÍKOVÁ, S. - MICHALOOV, L. TÓTHOVÁ, V. (eds.) 2. Košické dni trestného práva. Poškodený trestným činom a obete trestných činov, možnosti posilňovania ich procesných oprávnení. Zborník vedeckých príspevkov z interdisciplinárnej celoštátnej vedeckej konferencie s medzinárodnou účast'ou. Košice : Univerzita Pavla Jozefa Šafárika v Košiciach, 2018, s. 173-179; a JAKAB, R. Právo poškodeného priestupkom na spravodlivý proces. In Štát a právo. Roč. 7, č. 1, 2020, s. 15-26.

${ }^{6}$ Napríklad SREBALOVÁ, M. Limity aplikácie zásad správneho trestania v praxi. In Přestupky a ř́zení o nich z pohledu teorie a praxe. Praha : Policejní akademie ČR, 2014, s. 236 a nasl.; FEČÍK, M. - FILOVÁ, A. Komentár k § 194 Správneho súdneho poriadku. In BARICOVÁ, J. - FEČÍK, M. - ŠTEVČEK, M. - FILOVÁ, A. a kol. Správny súdny poriadok. Komentár. Bratislava : C. H. Beck, 2018, s. 976-977.

${ }^{7}$ SEMAN, T. Vplyv ustanovení o správnej žalobe vo veciach správneho trestania (§ $194-\S 198$ zákona č. 162/2015 Z. z. Správny súdny poriadok, v znení neskorších predpisov) na administratívne konanie vo veciach správneho trestania. In FRUMAROVÁ, K (ed.) Správni soudnictví - 15 let existence soudního ř́du správního vs. prvotni zkušenosti s aplikaci nového správneho súdneho poriadku. Olomouc : Iuridicum Olomoucense, 2018, s. 287.

${ }^{8}$ Podl'a $§ 195$ písm. c) zákona č. 162/2015 Z. z. Správny súdny poriadok v znení neskorších predpisov (d’alej len Správny súdny poriadok) správny súd nie je vo veciach správneho trestania viazaný rozsahom a dôvodmi žaloby, ak ide o základné zásady trestného konania podl'a Trestného poriadku, ktoré je potrebné použit' na správne trestanie. 


\section{Metódy rozšírenia aplikácie restoratívnych princípov pri správnom trestaní}

Rozšírenie možností využívania obnovujúcich prvkov vo veciach administratívneho trestania možno za súčasného právneho stavu dosiahnut' viacerými metódami. Pri absencii aktivity zákonodarcu, ktorá by normatívne zohl'adnila restoratívne trendy, možno ich posilnenie dosiahnut' nasledujúcimi spôsobmi:

1) nachádzaním extenzívnych možností subsidiárnej aplikácie existujúcej úpravy všeobecného správneho konania,

2) aplikáciou trestnoprávnej regulácie, ktorej použitia sa zákonodarca expressis verbis dovoláva v $§ 195$ písm. c) Správneho súdneho poriadku,

3) analogickou aplikáciou inej trestnoprocesnej regulácie než úpravy predvídanej v § 195 písm. c) Správneho súdneho poriadku, za podporného použitia záverov ustálenej súdnej praxe.

\section{II.1 Extenzívny výklad existujúcej právnej úpravy správneho trestania}

\section{II.1.1 Extenzívny výklad úpravy zmieru v priestupkovom konaní}

Prvou alternatívou je hl’adanie možností rozširujúcej interpretácie platnej a účinnej právnej úpravy. Možnosti aplikovania restoratívnej justície sa v avizovanom prípade nachádzajú v internom prostredí verejnej správy. Výhodou, najmä aj pre vykonávatel’ov verejnej správy, je skutočnost', že pri využití tejto metódy nedochádza k vzájomnej interakcii viacerých právnych odvetví.

Praktickým príkladom aplikovatel'nosti tohto prístupu môžu byt' úvahy o aplikovatel'nosti zmieru v konaní o správnych deliktoch.

Inštitút zmieru je na účely priestupkového konania špeciálne upravený v $§ 78$ zákona o priestupkoch. ${ }^{9}$ Podl'a tohto ustanovenia: „Pri priestupku urážky na cti sa okresný úrad pokúsi urazeného na cti a obvineného z priestupku zmierit'. "

Všeobecná úprava zmieru v správnom konaní je obsiahnutá v $\$ 48$ zákona o správnom konaní. ${ }^{10}$ Podl'a tohto ustanovenia: ,(1) Ak to pripúšta povaha veci, môžu účastníci konania medzi sebou so schválením správneho orgánu uzavriet’ zmier. Správny orgán zmier neschváli, ak odporuje právnym predpisom alebo všeobecnému záujmu. (2) Proti schválenému zmieru sa nemožno odvolat'. Schválený zmier je vykonatel’ný. “ Marginálne sa problematiky zmieru dotýka aj § 3 ods. 4 alinea 2 zákona o správnom konaní, podl'a ktorého: „Ak to povaha veci pripúšta, má sa správny orgán vždy pokúsit’ o jej zmierne vybavenie."

Ustanovenie § 78 zákona o priestupkoch je po vecnej i formálnej stránke konštruované pomerne reštriktívne (predovšetkým je použitel'né len pri priestupku urážky na

\footnotetext{
${ }^{9}$ Zákon Slovenskej národnej rady č. 372/1990 Zb. o priestupkoch v znení neskorších predpisov (d’alej len zákon o priestupkoch).

${ }^{10}$ Zákon č. 71/1967 Zb. o správnom konaní (správny poriadok) v znení neskorších predpisov (d’alej len zákon o správnom konaní).
} 
cti), čo býva zo strany predstavitel’ov teórie a praxe vnímané pomerne kriticky. Vo vede správneho práva procesného sa uznáva, že toto ustanovenie je špeciálnou úpravou vo vzt'ahu k všeobecnej úprave zmieru obsiahnutej v zákone o správnom konaní. To nevytvára priestor na možnosti subsidiárnej aplikácie všeobecnej úpravy administratívneho zmieru v konaní o priestupkoch. Zástancovia nemožnosti aplikovania $\S 48$ zákona o správnom konaní vo veciach správneho trestania argumentujú tiež tým, že zákonodarca marginálnu rubriku nad $\S 78$ zákona o priestupkoch nenadpísal ,niektoré ustanovenia o zmieri“ (čo by mohlo vytvorit' priestor na odôvodnenie uzavierania zmieru podl'a § 48 zákona o správnom konaní vo veciach správneho trestania), ale „zmier“ (čo neumožňuje uzavriet' zmier podl'a zákona o správnom konaní vo veciach správneho trestania). ${ }^{11}$ Tieto prístupy nevytvárajú dostatočný priestor na uskutočnenie zmierovacieho konania $\mathrm{v}$ trestných veciach pred správnym orgánom. Domnievam sa, že môže existovat' aj alternatívny prístup k pomeru § 78 zákona o priestupkoch $\mathrm{k} \S 48$ zákona o správnom konaní.

Nemožno popriet', že $§ 78$ zákona o priestupkoch je vo vzt’ahu k $§ 48$ zákona o správnom konaní špeciálnou úpravou. Len $\mathrm{z}$ pomeru špeciality však nemožno dovodit' vylúčenie aplikácie § 48 zákona o správnom konaní v konaní o priestupkoch. Pomer lex specialis - lex generalis ${ }^{12}$ nevyhnutne neznamená vylúčenie aplikácie všeobecnej úpravy pri existencii špeciálnej úpravy.

Žiada sa podotknút', že napríklad dokazovanie vo veciach priestupkov je upravené v zákone o priestupkoch (lex specialis) len okrajovo (najmä v ustanovení o odňatí a prikázaní veci). ${ }^{13}$ Toho dôsledkom je všeobecne uznávaná ${ }^{14}$ potreba subsidiárnej aplikácie všeobecnej úpravy dokazovania podl'a zákona o správnom konaní. Obdobné závery možno vyvodit' i vo vzt'ahu k iným nekomplexne upraveným inštitútom priestupkového práva, napríklad vo vzt’ahu k právnej úprave doručovania ${ }^{15}$ alebo odvolania. ${ }^{16} \mathrm{~V}$ týchto prípadoch sa subsidiárna aplikácia zákona o správnom konaní uznáva napriek tomu, že zákonodarca príslušné marginálne rubriky (rovnako ako v prípade zmieru podl’a zákona o priestupkoch) nenadpísal „,niektoré ustanovenia o príslušnom inštitúte priestupkového práva (dokazovani, doručovani, odvolaní)“.

Podl'a môjho názoru je možné tradičné ponímanie vzt'ahu špeciality (lex specialis lex generalis) osobitného predpisu a všeobecného predpisu o správnom konaní uplatnit' aj na účely zmieru v priestupkovom konaní, ${ }^{17}$ a to s poukázaním na všeobecnú subsidia-

\footnotetext{
${ }^{11}$ Pozri napríklad JAKAB R. Právo poškodeného priestupkom na spravodlivý proces, s. 15-26.

${ }^{12}$ Bližšie DOBROVIČOVÁ, G. Právne normy. In BRÖSTL, A. a kol. Teória práva. Plzeň : Aleš Čeněk, 2013, s. 79.

${ }^{13}$ Ustanovenie $§ 75$ zákona o priestupkoch.

${ }^{14}$ Napríklad MOLITORIS, P. Vzt'ah medzi zákonnostou a prípustnostou dôkazov vo veciach správneho trestania. In STUDIA IURIDICA Cassoviensia. Roč. 6, 2018, č. 1, 2018, s. 33-41.

${ }^{15}$ Ustanovenie $\S 80$ zákona o priestupkoch.

${ }^{16}$ Ustanovenia $\S 81$ až $§ 82$ zákona o priestupkoch.

${ }^{17} \mathrm{H}$. Spišiaková túto alternatívu implicitne tiež pripúšt'a, ked' uvádza, že dobrovol’né nahradenie škody obvineným možno riešit' ako (vo svojej podstate) čiastkový zmier procesným postupom podla $§ 48$ zákona o správnom konaní. Pozri SPIŠIAKOVÁ, H. Zákon o priestupkoch. Komentár. Bratislava : Wolters Kluwer, 2015, s. 429 a nasl.
} 
ritu zákona o správnom konaní vyjadrenú v $§ 1$ ods. 1 tohto zákona. ${ }^{18}$ Právnoaplikačným výrazom uvedeného môže byt' skutočnost', že zmier v priestupkovom konaní možno uzavriet' nielen v prípade priestupku urážky na cti, ale aj v konaní o iných priestupkoch, ktorých povaha uzavretie zmieru pripúšt’a. Tento záver môže podporovat' i fakt, že administratívnoprocesnému imperatívu pokusu o uzavretie zmieru priznáva zákon o správnom konaní adekvátnu dôležitost' prostredníctvom jeho zakotvenia v rámci základných pravidiel konania. ${ }^{19}$

Vyvstáva potreba vymedzenia metodiky uzavierania zmieru v priestupkovom konaní. Domnievam sa, že procesný postup správneho orgánu by mohol byt’ nasledujúci: aprávny orgán by sa mal v prípade každého priestupku, ktorého povaha to pripúšs’a, o uzavretie zmieru pokúsit'. Ide o procesnú povinnost' správneho orgánu. ${ }^{20}$ Pri priestupku urážky na cti, ak by šlo o zmier medzi obvineným z priestupku a urazeným na cti, by právnym základom pokusu o zmier boli primárne $\S 78$ zákona o priestupkoch, sekundárne $\S 3$ ods. 2 zákona o správnom konaní. Taký zmier by titulom prednostnej aplikácie $§ 78$ zákona o priestupkoch nepodliehal schváleniu správnym orgánom. ${ }^{21} \mathrm{~V}$ ostatných prípadoch by právny podklad procesnej zmierovacej povinnosti správneho orgánu predstavoval $\S 3$ ods. 2 zákona o správnom konaní. Ak by došlo k zmieru, zmier by podliehal schváleniu správnym orgánom, pretože niet právneho podkladu na jeho vykonatel'nost' bez schválenia. $V$ d’alšom procesnom postupe po márnom pokuse správneho orgánu o zmier by sa zmier mohol uzavriet' z iniciatívy účastníkov konania (napríklad z iniciatívy poškodeného). Podkladom uzavretia zmieru by bol $\S 48$ zákona o správnom konaní, a to bez ohl'adu na skutkovú podstatu priestupku, pri dodržaní všeobecnej požiadavky povahy priestupku, ktorá uzavretie zmieru pripúšt’a. I tu by zmier musel byt' správnym orgánom schválený. Ak by sa zmier uzavieral medzi obvineným z priestupku a poškodeným, vzniká otázka, či by na možnost' schválenia zmieru vplývala právna povaha poškodeného subjektu, predovšetkým otázka jeho verejnoprávneho alebo súkromnoprávneho charakteru. Pri hl'adaní a nachádzaní odpovede je potrebné začat' legálnym vymedzením poškodeného. Poškodeným sa podl'a $\S 70$ ods. 1 zákona o priestupkoch rozumie ten, komu bola

${ }^{18}$ Podl'a $§ 1$ ods. 1 zákona o správnom konaní: „, Tento zákon sa vzt’ahuje na konanie, v ktorom v oblasti verejnej správy správne orgány rozhodujú o právach, právom chránených záujmoch alebo povinnostiach fyzických osôb a právnických osôb, ak osobitný zákon neustanovuje inak."

${ }^{19}$ Ustanovenie $\S 3$ ods. 4 alinea 2 zákona o správnom konaní.

${ }^{20}$ Najvyšší súd SR v rozsudku sp. zn. 2Sžo/27/2011 zo dňa 18. apríla 2012 uviedol: „Správny orgán prvého stupňa postupoval v súlade s priestupkovým zákonom, ked' sa pokúsil urazeného a obvineného zmierit'. Zákon neustanovuje výslovne, či sa príslušný orgán musí pokúsit’ o uzavretie zmieru, z jeho dikcie však možno mat'za to, že tento postup zákonodarca zamýšl’al. “

${ }^{21}$ Podl’a $§ 76$ ods. 1 písm. k) zákona o priestupkoch správny orgán konanie o priestupku zastaví, ak sa v ňom zistí, že v konaní o urážke na cti došlo ku zmieru. $Z$ tejto normatívnej dikcie nie je možné vyvodit', na rozdiel od všeobecnej úpravy správneho konania, schval'ovanie zmieru orgánom konajúcim o priestupku. Podobne uvažuje SPIŠIAKOVÁ, H. Zákon o priestupkoch. Komentár, s. 496. P. Molitoris dodáva, že v prípade uzavretia zmieru správny orgán konanie obligatórne zastaví. Z toho je možné vyvodit’, že správnemu orgánu sa ukladá povinnost' zastavit' konanie aj $\mathrm{v}$ prípade, ak obsah zmieru je $\mathrm{v}$ rozpore so všeobecným záujmom, prípadne v prípade, ak by bol navrhovatel' obvineným k zmieru riadne prinútený. Pozri MOLITORIS, P. Konsenzuálne prostriedky alternatívneho riešenia sporov v správnom konaní. Košice : Univerzita Pavla Jozefa Šafárika v Košiciach, 2016, s. 114. 
priestupkom spôsobená majetková škoda, ak uplatnil nárok na jej náhradu v konaní o priestupku. Ked’že $v$ rámci tejto definície sa na označenie poškodeného používa všeobecný výraz „ten“, je zrejmé, že poškodeným môže byt' tak fyzická osoba, ako aj právnická osoba. Ked’že platná právna úprava neustanovuje výluku vo vzt'ahu k určitému charakteru poškodeného, zdá sa, že zmier v procesnej pozícii poškodeného môže uzavriet’ aj právnická osoba verejného práva. Frumarová však dvíha pomyselný varovný prst a dodáva, že v týchto prípadoch by zo strany správneho orgánu malo byt' vel'mi pozorne a zodpovedne posudzované naplnenie účelu a podstaty zmieru a malo by sa skúmat', či je z pohl'adu verejného záujmu takéto riešenie postačujúce. ${ }^{22}$

Treba akcentovat', že tieto úvahy predstavujú snahu o extenziu využívania zmieru v priestupkovom konaní za súčasného právneho stavu. Možno sa stotožnit' s právnymi závermi, že platná právna úprava je po normatívnej stránke nedostačujúca, vyžadujúca komplexné normatívne zmeny. ${ }^{23}$

\section{II.1.2 Extenzívny výklad úpravy zmieru v konaní o inom správnom delikte}

Osobitné predpisy správneho práva, nezriedka obsahujúce popri hmotnoprávnej úprave iných kategórií správnych deliktov než priestupkov ${ }^{24}$ i procesné aspekty konania o nich, zmier neupravujú. Skončenie veci zmierom bude prípustné v každom prípade, ak budú naplnené všeobecné podmienky uzavretia zmieru (§ 48 zákona o správnom konaní). Zákonnost' tohto ustanovenia treba odôvodnit' všeobecnou subsidiaritou zákona o správnom konaní na konanie o iných správnych deliktoch.

\section{II.2 Aplikácia trestnoprávnej regulácie, ktorej použitia sa zákonodarca expressis verbis dovoláva v $\$ 195$ písm. c) Správneho súdneho poriadku}

Alternatívnym postupom $\mathrm{k}$ rozšíreniu použitia obnovujúcich prístupov titulom subsidiarity zákona o správnom konaní môže byt' využitie zákonodarcovej predikcie aplikácie trestnoprocesnej zásady oportunity (účelnosti, účelovosti) v administratívnom trestaní. Tento postup je v porovnaní s predošlou možnost’ou interpretačne náročnejší, ked’že sa nachádza na pomedzí troch právnych odvetví (správneho práva, trestného práva a civilného práva procesného).

Najskôr je potrebné upriamit' pozornost' na presah do správneho súdneho konania. V § 195 písm. c) Správneho súdneho poriadku sa orgánom konajúcim o správnom delikte ukladá povinnost' zohl'adnit' základné zásady trestného konania podl'a Trestného poriadku. Základnými zásadami trestného konania treba rozumiet' predovšetkým zásady normatívne vyjadrené v $§ 2$ Trestného poriadku. ${ }^{25}$

${ }^{22}$ FRUMAROVÁ, K. Narovnání - nově zavedený institut tzv. odklonu do řízení o přestupku. In Správní právo, roč. 50, č. $7-8,2017$, s. 465 .

${ }^{23}$ JAKAB, R. Právo poškodeného priestupkom na spravodlivý proces, s. 20 a nasl.

${ }^{24} \mathrm{Ku}$ klasifikácii správnych deliktov napríklad MUSIL, J. Teoretická a ústavní východiská správního trestání. In Acta Universitatis Carolinae Iuridica 1/2010. O veřejné správě, č. 1, 2010, s. 55.

${ }^{25}$ Zákon č. 301/2005 Z. z. Trestný poriadok v znení neskorších predpisov (d’alej len Trestný poriadok). 
Následne sa žiada identifikovat' spojitost' medzi rozširovaním aplikácie restoratívnych princípov v správnom konaní a základnými zásadami trestného konania. Tá sa nachádza v aplikácii podkladu na výnimku zo zásady legality ( $\$ 2$ ods. 5 Trestného poriadku) v konaní o správnych deliktoch. Podl'a $\S 2$ ods. 5 Trestného poriadku: „Prokurátor v trestnom konaní zastupuje štát. Ak tento zákon, medzinárodná zmluva vyhlásená spôsobom ustanoveným zákonom (d'alej len „medzinárodná zmluva“) alebo rozhodnutie medzinárodnej organizácie, ktorým je Slovenská republika viazaná, neustanovuje inak, prokurátor je povinný stihhat' všetky trestné činy, o ktorých sa dozvedel. “Zvýraznená čast' citovaného ustanovenia vytvára priestor na uplatnenie výnimky zo zásady legality, teda na aplikáciu zásady oportunity (účelnosti, účelovosti) v trestnom konaní. Právnym podkladom (aplikačným odôvodnením) na použitie zásady oportunity v správnom konaní bude $\S 195$ písm. c) Správneho súdneho poriadku, ktorý sa použitia tejto výnimky na účely administratívneho trestania $\mathrm{v}$ podstate expressis verbis dovoláva.

Konkrétnym prejavom uplatnenia zásady oportunity v trestnom procese je možnost' prokurátora skončit trestnú vec inak ako podaním obžaloby, napríklad uzavretím zmieru (§ 220 a nasl. Trestného poriadku). ${ }^{26}$ Takáto možnost' sa dáva prokurátorovi bez pozitívnej alebo negatívnej vecnej limitácie, t. j. bez ustanovenia okruhu trestných činov, vo vzt’ahu ku ktorým sa uzavretie zmieru pripúšt’a, respektíve nepripúšt'a. Povedané inak, odkazovacia norma Správneho súdneho poriadku vyžaduje aplikáciu zásady účelnosti, objektivizovanej v Trestnom poriadku, aj v správnom trestaní. Zásada účelnosti vytvára prokurátorovi priestor konat' $\mathrm{v}$ trestnom konaní o takom zmieri, ktorý sa neobmedzuje na jediný alebo viacero určitých skutkových podstát. ${ }^{27}$ Toto zistenie môže odôvodnit' prorestoratívne administratívnoprocesné tendencie, ktoré sa prejavia v možnosti ukončit' každú administratívnu trestnú vec zmierom (pri existencii pozitívnych podmienok možnosti skončenia veci zmierom).

Je otázne, či na základe tejto koncepcie možno pripustit’ komplexnú aplikáciu trestnoprocesného zmieru ( $\$ 220$ a nasl. Trestného poriadku). Správny súdny poriadok prikazuje použit’ v správnom konaní „,zásady“ a nie „normy“ trestného konania. Medzi zásadami a normami existuje množstvo rozdielov, ktorých dosahy presahujú rámec tejto práce. Domnievam sa, že druhá koncepcia by mala byt' vecne limitovaná obsahom zásady implikovanej v § 2 ods. 5 Trestného poriadku a jej výlučne nevyhnutnými presahmi. Nevyhnutný presah sa objektivizuje $\mathrm{v}$ takom systematickom výklade zásady účelnosti, ktorý komplexným spôsobom ozrejmuje jej význam. V hraniciach tejto paroly je napríklad vylúčenie vecnej limitácie uzavierania zmieru pre účely správneho konania.

${ }^{26}$ Rovnako PALKOVIČ, J. Komentár k ustanoveniu $§ 2$ Trestného poriadku. In ČENTÉ̌̌, J. a kol. Trestný poriadok. Velký komentár. Bratislava : Eurokódex, 2014, s. 5; IVOR, J. Základné zásady trestného konania. In IVOR, J. -POLÁK, P. - ZÁHORA, J. Trestné právo procesné 1. Bratislava : Wolters Kluwer, 2017, s. 72.

${ }^{27}$ Ustanovenie $§ 195$ písm. c) Správneho súdneho poriadku $\rightarrow$ Ustanovenie $§ 2$ ods. 5 Trestného poriadku $\rightarrow$ Ustanovenie $§ 220$ a nasl. Trestného poriadku (vecne nelimitované). 


\section{II.3 Analogická aplikácia inej trestnoprocesnej regulácie než úpravy predvídanej v § 195 písm. c) Správneho súdneho poriadku, za podporného použitia záverov ustálenej súdnej praxe}

Tret’ou možnost'ou je extenzia obnovujúcich prístupov v správnom konaní analógiou. Analogická aplikácia inej trestnoprocesnej regulácie, než úpravy predvídanej v § 195 písm. c) Správneho súdneho poriadku, je pri podpornej aplikácii záverov súdnej praxe najväčšmi prepracovaným podkladom uzavierania zmieru v správnom konaní. Žiada sa dodat', že tento prístup tiež presahuje rámce verejnosprávnej regulácie.

Najprv je potrebné pripomenút', že právna úprava deliktného práva vo verejnej správe je medzerovitá, v určitých aspektoch nezohl'adňujúca právo na spravodlivý proces. Košičiarová k tomu uvádza, že vykonávatelia verejnej správy v podmienkach Slovenskej republiky aplikujú zákony, ktoré nedostatočným spôsobom odpovedajú na otázku, akým spôsobom majú postupovat' pri vyvodzovaní zodpovednosti za správne delikty. Predmetný stav je zapríčinený nevyváženost'ou miery úpravy pravidiel týkajúcich sa prejednávania a postihu jednotlivých kategórií správnych deliktov. ${ }^{28}$ Hoci ide o oblast', kde by sa mala analógia používat' čo najmenej, je to tak, iba zdanlivo paradoxne, práve naopak, pretože prax sa musí trvalo vyrovnávat's absenciou všeobecnej časti tohto subsystému správneho práva. ${ }^{29}$ Táto skutočnost' odôvodňuje využívanie analógie trestného práva ${ }^{30}$ pri správnom trestaní. Absenciu dostatočnej úpravy správneho trestania v tomto zmysle výrazne dopíňajú rozhodovacou činnost'ou najvyššie súdne autority, a to predovšetkým Najvyšší súd Slovenskej republiky a Ústavný súd Slovenskej republiky. ${ }^{31} \mathrm{Na}$ korigovanie problematickosti postupu podl'a analógie pri používaní trestnoprávnych noriem v sankčnom prostredí verejnej správy má významný dosah aj rozhodovacia činnost' Európskeho súdu pre l'udské práva. Priestupky je možné na podklade záverov Európskeho súdu pre l'udské práva označit' za delikty trestnej povahy. To je dôvod, prečo sa na ich prejednávanie vzt’ahuje právo na spravodlivý proces garantované v čl. 6 ods. 1 Dohovoru o ochrane l'udských práv a základných slobôd v prípade, kým sú naplnené tzv. Engelovské kritériá. ${ }^{32}$ Povedané inak, Európsky súd pre l'udské práva vytvára doktrínu autonómneho posudzovania pojmov používaných Dohovorom o ochrane l'udských práv a zá-

${ }^{28}$ KOŠIČIAROVÁ, S. Potrebuje Slovenská republika zákon o zodpovednosti za správne delikty? In Správní právo, roč. 50, č. 7 - 8, 2017, s. 447.

${ }^{29}$ MATES, P. Analogie ve správním právu. In Správní právo, roč. 44, č. 6, 2011, s. 349

${ }^{30}$ Analógia sa delí na analógiu zákona (analogia legis) a analógiu práva (analogia iuris). Analógia zákona (analogia legis) je postup, pri ktorom sa na riešenie právnej veci použije právna norma, ktorá reguluje prípad najpodobnejší (analogický). Normatívny právny akt je teda aplikovaný na prípad, ktorý nie je vyslovene upravený právnou normou, ale sa odlišuje od prípadov regulovaných právom len niektorými druhotnými, nepodstatnými znakmi. Analógia práva v skutočnosti nie je analógiou, ked’že predstavuje len použitie vel'mi hmlistých všeobecných zásad právnych. Ide o rozhodnutie podl’a rozumného právneho uváženia. Skutočnou analógiou je len analógia zákona. Pozri KNAPP, V. Teoria práva. Praha : C. H. Beck, 1995, s. 172 a KANÁRIK, I. Výklad práva. In BRÖSTL, A. a kol. Teória práva. Plzeň : Aleš Čeněk, 2013, s. 142.

${ }^{31}$ MILUČKÝ, J. Vybrané otázky administratívneho sankcionovania v praxi. In Správní právo, roč. 52, č. 7 , 2019, s. 369.

${ }^{32}$ Pozri MOLITORIS, P. Priestupkové konanie. In JAKAB, R. - MOLITORIS, P. Správne právo procesné. Košice : Univerzita Pavla Jozefa Šafárika v Košiciach, 2018, s. 187. 
kladných slobôd. V zmysle avizovanej doktríny nie je podstatné, či skutok, o ktorom sa vedie konanie a za ktorý hrozí trest, je vnútroštátnym právnym predpisom nazvaný trestný čin alebo správny delikt. Táto doktrína zohrala významnú úlohu v slovenskej judikatúre, pretože na jej základe začali správne súdy od devät'desiatych rokov minulého storočia uplatňovat' zásady trestného práva aj pre oblast' správneho trestania. Impulzom k tomu sa stal rozsudok Európskeho súdu pre l’udské práva vo veci Lauko v. Slovenská republika ${ }^{33}$, z ktorého vyplynulo, že konanie o priestupku zahŕňa rozhodovanie o ,trestnom obvinení“v zmysle čl. 6 Dohovoru o ochrane l’udských práv a základných slobôd. Ďalším významným štrasburským rozsudkom, ktorý ovplyvnil slovenské správne súdnictvo, bol rozsudok vo veci Čanády v. Slovenská republika ${ }^{34}$, podl'a ktorého všeobecný charakter právnych ustanovení upravujúcich priestupky spolu so zastrašujúcim a represívnym účelom sankcie ukladanej za porušenie stačí na preukázanie toho, že na účely čl. 6 ods. 1 Dohovoru o ochrane l’udských práv a základných slobôd sú priestupky svojou povahou trestné. ${ }^{35}$ Ústavný súd Slovenskej republiky, vychádzajúc z čl. 6 ods. 1 prvej vety Dohovoru o ochrane l'udských práv a základných slobôd, z odporúčania Výboru ministrov Rady Európy č. R (91) pre členské štáty o správnych sankciách schváleného Výborom ministrov Rady Európy 13. februára 1991, ako aj z judikatúry Európskeho súdu pre l'udské práva [napríklad rozsudok Neumeister v. Rakúsko z júla 1976)], pripomína, že trestanie za správne delikty musí podliehat' rovnakému režimu ako trestný postih za trestné činy. Je preto nevyhnutné poskytnút' záruky a práva, ktoré sú zakotvené v Trestnom zákone a Trestnom poriadku nielen obvinenému z trestného činu, ale aj subjektu, voči ktorému je vyvodzovaná administratívnoprávna zodpovednost', čo napokon vyplýva aj zo zásady č. 6 odporúčania o správnych sankciách, podl'a ktorej je nevyhnutné v rámci správneho konania vo veciach správnych sankcií poskytovat' okrem záruk spravodlivého správneho konania v zmysle rezolúcie č. (77) 31 aj pevne zavedené záruky v trestnom konaní. ${ }^{36}$

Rozsah analógie v správnom trestaní je však vecne obmedzený. Na použitie analógie $\mathrm{v}$ tejto oblasti by mali byt' kumulatívne naplnené podmienky: medzera vo všeobecne záväznom právnom predpise (i), použitím analógie neutrpí páchatel' (ii) a použitím analógie sa neohrozí príslušný chránený záujem (iii). Analógia pritom (iv) nesmie spočívat' v používaní celých inštitútov, ale má slúžit' na vykrývanie tých častí, ktoré sú síce čiastočne upravené, ale daná úprava je len rámcová a teda nedostatočná. ${ }^{37}$

Prípustnost' aplikovania zmieru analógiou $\mathrm{k}$ trestnoprocesnej úprave je potrebné s vymedzenými kritériami testovat'. Domnievam sa, že jednotlivé kroky tohto testu môžu zniet' takto:

\footnotetext{
${ }^{33}$ Rozsudok Európskeho súdu pre l'udské práva z 2. septembra 1998, č. st’ažnosti 26138/95.

${ }^{34}$ Rozsudok Európskeho súdu pre l'udské práva zo 16. novembra 2004, č. st’ažnosti 53371/99.

${ }^{35}$ KOŠIČIAROVÁ, S. Povinnost' správneho súdu aplikovat' trestnoprávne zásady vo veciach správneho trestania. In Justičná revue, roč. 68, č. 8 - 9, 2016, s. 890-891.

${ }^{36}$ Nález Ústavného súdu Slovenskej republiky sp. zn. III. ÚS 571/2015 zo dňa 12. apríla 2016.

${ }^{37}$ CEPEK, B. Vzt’ah a možnosti aplikácie ustanovení trestného práva na účely správneho trestania. In KOŠIČIAROVÁ, S. - BEDE, D. (eds.) Zásady zákona o správnom trestaní. Bratislava : Právnická fakulta Trnavskej univerzity v Trnave, 2017, s. 57.
} 
1) Existuje v otázke zmieru v administratívnom konaní medzera vo všeobecne záväznom predpise?

2) Nebude skončenie administratívnej veci zmierom obvinenému zo správneho deliktu na tarchu (analogia in malam partem)?

3) Neohrozí sa zmiernym vybavením veci právom chránený záujem?

4) Bude analogická aplikácia trestného zmieru znamenat' použitie inštitútu, ktorý deliktuálne správne právo nepozná, alebo pôjde len o doplnenie existujúceho nedostatočne upraveného inštitútu?

\section{Ad 1)}

Medzera vo všeobecne záväznom predpise v otázke zmieru v správnom trestaní existuje. Právna úprava zmieru je medzerovitá v tom zmysle, že sa vzt’ahuje len na jedinú skutkovú podstatu priestupku (vecné obmedzenie uzavierania zmieru), a tiež v tom, že umožňuje uzavretie zmieru len medzi urazeným na cti a obvineným z priestupku (subjektívne obmedzenie uzavierania zmieru). ${ }^{38}$

\section{Ad 2)}

Analógia je vo verejnoprávnom trestaní prípustná tradične, len ak je v prospech páchatel'a (in bonam partem), teda ak nevedie k zhoršeniu postavenia páchatel'a verejnoprávneho deliktu alebo inému zhoršeniu postavenia páchatel'a $\mathrm{z}$ hl'adiska verejnoprávneho trestania. ${ }^{39}$ Vybavenie veci zmierom, najmä v úvodných fázach priestupkového konania, nemusí znamenat' plné využitie všetkých inštitútov garantujúcich právo na spravodlivý proces. Možnost' takejto odchýlky sa však determinuje nevyhnutnou podmienkou uzavretia zmieru, ktorou je súhlas obvineného so zmiernym vybavením veci. V takom prípade sa môžu prejavit' pozitíva odklonného vybavenia administratívnej veci. Vhodnost' a potrebu naznačeného postupu je možné v tomto smere vnímat' nielen v kontexte rýchlosti, hospodárnosti a efektívnosti konania, ale i špecificky - z hl'adiska posilňovania prvkov restoratívnej justície. ${ }^{40}$ Domnievam sa, že vybavenie veci zmierom nebude obvinenému na t’archu, ba práve naopak, v konečnom dôsledku mu môže byt' v porovnaní s klasickým priebehom konania na prospech (analogia in bonam partem).

\section{Ad 3)}

Príslušným právom chráneným záujmom treba rozumiet' objekt (právny statok) správneho deliktu. Plauzibilitu tohto kroku treba hl'adat' v negatívnej podmienke zmieru, t. j. v nemožnosti zmierneho vybavenia, ak to povaha veci nepripúšt’a. Slovné spojenie

\footnotetext{
${ }^{38} \mathrm{~K}$ rôznym názorom na túto otázku pozri MOLITORIS, P. Konsenzuálne prostriedky alternatívneho riešenia sporov v správnom konaní, s. 115.

${ }^{39}$ FERENČÍKOVÁ, S. Základné zásady trestnej zodpovednosti. In Zeszyty Naukowe Universytetu Rzeszowskiego: seria prawnicza. Vol. 94, č. 19, 2016, s. 43.

${ }^{40}$ ČOPKO, P. Odklony ako procesné alternatívy k trestu odňatia slobody. In ROMŽA, S. - FERENČÍKOVÁ, S. - MICHALOV, L. (eds.) IV. Košické dni trestného práva. Privatizácia výkonu trestu odňatia slobody, sci-fi alebo jediná možnost?? Zborník vedeckých prác. Košice : Univerzita Pavla Jozefa Šafárika v Košiciach, 2020, s. 262.
} 
„povaha veci“ implikuje najmä objekt správneho deliktu. Zmier tak nebude prípustný napríklad pri správnych deliktoch, ktorých objektom je bezporuchový výkon správy. Zastávam názor, že v ostatných prípadoch právom chránený záujem neutrpí zmiernym vybavením veci ujmu.

\section{Ad 4)}

Používanie analógie pri správnom trestaní musí byt' z hl’adiska inštitútov limitované. Medze na dotváranie práva sú pre avizovaný prípad ohraničované hranicami kvantitatívneho rázu. Orgány rozhodujúce o správnom delikte môžu analógiou doplnit’ iba to, čo v úprave už existuje, prinajmenšom rámcovo, ale nemôžu do nej včlenit' inštitúty, ktoré sa v danom odvetví vôbec nevyskytujú. Inak povedané, je vylúčené doplňovat' medzery obsahového charakteru. ${ }^{41}$

Je zrejmé, že potreba existencie analógiou dopĺn̆aného inštitútu je v prípade zmieru v priestupkovom konaní naplnená. Popri vecných nedostatkoch je však priestupkový zmier upravený nedostatočne aj po formálnej stránke. Právna úprava je koncentrovaná do holého jediného ustanovenia (jediná veta). Ak sa teda pripustí analogická aplikácia trestného zmieru, pôjde len o precizáciu existujúceho administratívneho inštitútu pre potreby správnej praxe. Nepôjde o analogické používanie trestnoprocesného inštitútu v podmienkach správneho konania absolútne neupraveného (napríklad „,dohoda o uznaní viny a prijatí trestu za správny delikt“, ,„podmienečné zastavenie konania o správnom delikte“ alebo „podmienečné zastavenie konania o správnom delikte spolupracujúceho obvineného“).

Kladné odpovede na položené otázky otvárajú priestor na významné možnosti (i) subjektívneho rozšírenia a (ii) obsahového spodrobnenia administratívnej úpravy zmieru využitím metódy analógie $k$ ustanoveniam $\$ 220$ a nasl. Trestného poriadku. Výsledkom bude spomedzi všetkých alternatív obsahovo najväčšmi prepracovaný administratívny zmier. Tento prístup totiž prekonáva jednak obmedzenost' úpravy všeobecného správneho konania (prvá koncepcia), ako aj obmedzenost' konštrukcie § 195 Správneho súdneho poriadku (druhá koncepcia). Na druhej strane, nie všetky náležitosti trestného zmieru sú v správnom konaní de lege lata aplikovatel'né.

Analógiou je možné v správnom konaní aplikovat' najmä nasledujúce normatívne požiadavky Trestného poriadku:

- podmienku uzavretia zmieru spočívajúcu v tom, aby obvinený zo správneho deliktu vyhlásil, že spáchal skutok, ktorý sa mu kladie za vinu, a nie sú odôvodnené pochybnosti o tom, že jeho vyhlásenie bolo vykonané slobodne, vážne a určito; ${ }^{42}$

- podmienku uzavretia zmieru spočívajúcu v tom, že obvinený zo správneho deliktu nahradil škodu, pokial' bola činom spôsobená, alebo urobil iné opatrenia na náhradu škody, alebo inak odstránil ujmu vzniknutú správnym deliktom; ${ }^{43}$

\footnotetext{
${ }^{41}$ MATES, P. Analogie ve správním právu, kdy ano a kdy ne. In Správní právo, roč. 47, č. 1 - 2, 2014,

${ }^{42}$ Ustanovenie $\S 220$ ods. 1 písm. a) Trestného poriadku.

${ }^{43}$ Ustanovenie $\S 220$ ods. 1 písm. b) Trestného poriadku.
} s. 48. 
- presvedčenie správneho orgánu o tom, že vzhl'adom na povahu a závažnost' spáchaného správneho deliktu, na mieru, akou bol správnym deliktom dotknutý verejný záujem, na osobu obvineného zo správneho deliktu a na jeho osobné a majetkové pomery je takýto spôsob rozhodnutia za dostačujúci; 44

- procesnú povinnost' správneho orgánu vypočut' obvineného a poškodeného pred rozhodnutím o schválení zmieru v prípade, ak to okolnosti prípadu vyžadujú, a to najmä na spôsob a okolnosti uzavretia zmieru, či zmier medzi nimi bol uzavretý dobrovol'ne a či súhlasia so schválením zmieru; výsluchom obvineného zo správneho deliktu správny orgán zistí, či obvinený rozumie obsahu obvinenia a či si je vedomý dôsledkov schválenia zmieru. Súčast’ou výsluchu obvineného zo správneho deliktu musí byt' vyhlásenie, že spáchal skutok, za ktorý sa voči nemu vedie správne konanie; ${ }^{45}$

- procesnú povinnost' správneho orgánu pred výsluchom obvineného a poškodeného poučit' o ich právach a o podstate zmieru; ${ }^{46}$

- ustanovenie zakotvujúce náležitosti rozhodnutia o zmieri, istotne s výnimkou peňažnej sumy určenej Ministerstvu spravodlivosti Slovenskej republiky na ochranu a podporu obetí trestných činov. Rozhodnutie o schválení zmieru a zastavení správneho konania by malo okrem všeobecných náležitostí obsahovat' opis skutku, ktorého sa zmier týka, jeho právne posúdenie, obsah zmieru zahrňujúci výšku nahradenej škody alebo škody, k náhrade ktorej sa obvinený zaviazal, alebo iné opatrenia na odstránenie ujmy vzniknutej správnym deliktom a výrok o zastavení správneho konania pre skutok, ktorého sa zmier týka; ${ }^{47}$

- ustanovenie o nemožnosti prihliadnut' na vyhlásenie o spáchaní skutku, ktorý sa obvinenému kladie za vinu, ako na dôkaz v d'alšom konaní, ak správny orgán zmier neschváli. ${ }^{48}$

Použitím analógie nie je možné odôvodnit' použitie nasledujúcich ustanovení Trestného poriadku:

- podmienku uzavretia zmieru spočívajúcu v tom, že obvinený zloží na účet súdu a v prípravnom konaní na účet prokuratúry peňažnú sumu určenú Ministerstvu spravodlivosti Slovenskej republiky na ochranu a podporu obetí trestných činov podl'a osobitného zákona, a táto peňažná suma nie je zrejme neprimeraná závažnosti spáchaného trestného činu. ${ }^{49}$ Táto podmienka je v správnom konaní nevykonatel'ná, pretože de lege lata neexistuje ani náznak jej primeranej administratívnoprocesnej alternatívy. Domnievam sa, že takáto (alebo obdobná) podmienka zmieru bude aplikovatel'ná v správnom konaní len v prípade jej legislatívneho zakotvenia;

- neprípustnost' uzavretia zmieru v prípade, ak bola trestným činom spôsobená smrt' osoby, ak je vedené trestné stíhanie pre korupciu, respektíve proti verejnému činitel'ovi alebo zahraničnému verejnému činitel'ovi pre trestný čin spáchaný v súvislosti s výko-

\footnotetext{
${ }^{44}$ Ustanovenie $\S 220$ ods. 1 Trestného poriadku.

${ }^{45}$ Ustanovenie $\S 221$ ods. 1 Trestného poriadku.

${ }^{46}$ Ustanovenie $\S 221$ ods. 2 Trestného poriadku.

${ }^{47}$ Ustanovenie $§ 223$ Trestného poriadku.

${ }^{48}$ Ustanovenie $\S 226$ Trestného poriadku.

${ }^{49}$ Ustanovenie $\S 220$ ods. 1 písm. c) Trestného poriadku.
} 
nom ich právomoci a v rámci ich zodpovednosti. ${ }^{50}$ Aplikovatel'nost' tohto ustanovenia sa vylučuje ipso facto, pretože tu ide o otázky súvisiace výlučne so súdne trestnými deliktmi (je napríklad nepochybné, že správnym deliktom nemôže byt' spôsobená smrt' osoby).

\section{Záver}

Slovenská právna úprava deliktného práva verejnej správy de lege lata nevytvára dostatočné priestory na uplatnenie restoratívnych princípov. Napriek tomu, že právna doktrína na uvedený právny stav upozorňuje, podrobne analyzuje platné normatívne riešenia priestupkových inštitútov a predostiera množstvo návrhov de lege ferenda, zákonodarcove aktivity sú prakticky nulové. Zdá sa však, že rozvoj obnovujúcich trendov nemusí kauzálne súvisiet's (ne)aktivitou normotvorcu. Je namieste uvažovat' o alternatívnych metódach, ktoré by umožnili rozvíjanie restoratívnej administratívnej spravodlivosti i za súčasného právneho stavu.

V predloženom príspevku boli predstavené tri spôsoby, ktoré by mohli byt' prostriedkom na rozšírenie aplikácie správneho zmieru ako významného prostriedku obnovujúcej povahy. Ich diferenciácia spočíva $\mathrm{v}$ metóde právneho riešenia, jej odôvodnení, ako aj v stupni konkrétnosti riešenia, ktoré predstavuje výstupný objekt príslušného spôsobu. Prvý prístup (subsidiarita všeobecnej úpravy správneho konania) by bol právne najjednoduchšie odôvodnitel'ný, súčasne by však poskytoval najmenej konkrétnu úpravu zmieru. Druhá koncepcia by sa aplikovala na základe výslovnej súdnoprocesnej blankety, takže by presahovala normatívne rámce správneho práva. Stupeň jej konkrétnosti by bol v zásade rovnaký ako v prvom prípade. Ostatná metóda by sa zakladala výlučne na analógii. Pravda, odborná verejnost' nemá na využívanie analógie v správnom trestaní ustálený názor. ${ }^{51}$ Potenciálnym nedostatkom tohto prístupu môže byt' problematickost' aplikácie trestnoprávnych noriem analogiae legis v správnom trestaní. Na druhej strane by metodológia tretej koncepcie priniesla najpodrobnejšiu úpravu zmieru.

Výhody a nevýhody každej z koncepcií otvárajú otázku vzájomnej kombinovatel'nosti koncepcií tak, aby výsledkom bol solídne odôvodnený prístup. Možným príkladom je použitie Trestného poriadku na základe blanketového ustanovenia $§ 195$ Správneho súdneho poriadku pri následnej analogickej aplikácii zmieru (§ 220 a nasl. Trestného poriadku). V tomto prípade by sa aplikácia práva začínala na základe $\S 195$ Správneho súdneho poriadku pri ustanovení $\S 2$ ods. 5 Trestného poriadku. Tým by sa poskytla použitiu Trestného poriadku dostatočná legitimita. Neostalo by však pri zásadách Trestného konania (druhá koncepcia), ale využitím tretej koncepcie (analogickej aplikácie noriem trestného práva procesného) by sa odôvodnilo použitie normatívnej úpravy trestného zmieru. Tým by sa na účely administratívneho trestania umožnilo aplikovanie detailizovanej a právnonormatívne prepracovanej úpravy. V každom prípade by bolo nevyhnutné, aby sa uvede-

\footnotetext{
${ }^{50}$ Ustanovenie $\S 220$ ods. 2 Trestného poriadku.

${ }^{51}$ Pozri SEMAN, T. Verejná správa v správnom súdnictve. Košice : Univerzita Pavla Jozefa Šafárika v Košiciach, 2016, s. 60.
} 
ný myšlienkový pochod správneho orgánu v súlade so základnou požiadavkou preskúmatel'nosti rozhodnutia dostatočne precízne prejavil $\mathrm{v}$ jeho odôvodnení.

\section{Literatúra}

CEPEK, B.: Vzt’ah a možnosti aplikácie ustanovení trestného práva na účely správneho trestania. In KOŠIČIAROVÁ, S. - BEDE, D. (eds.) Zásady zákona o správnom trestaní. Bratislava : Právnická fakulta Trnavskej univerzity v Trnave, 2017

C̆OPKO, P.: Odklony ako procesné alternatívy k trestu odňatia slobody. In ROMŽA, S., FERENČÍKOVÁ, S., MICHALOV, L. (eds.) IV. KOŠICKÉ DNI TRESTNÉHO PRÁVA. Privatizácia výkonu trestu odňatia slobody, sci-fi alebo jediná možnost? Zborník vedeckých prác. Košice: Univerzita Pavla Jozefa Šafárika v Košiciach, 2020

DOBROVIČOVÁ, G.: Právne normy. In BRÖSTL, A. a kol.: Teória práva. Plzeň: Aleš Čeněk, 2013

FEČÍK, M., FILOVÁ, A.: Komentár k § 194 Správneho súdneho poriadku. In BARICOVÁ, J., FEČÍK, M., ŠTEVČEK, M., FILOVÁ, A. a kol.: Správny súdny poriadok. Komentár. Bratislava: C. H. Beck, 2018

FERENČÍKOVÁ, S.: Základné zásady trestnej zodpovednosti. In Zeszyty Naukowe Universytetu Rzeszowskiego: seria prawnicza. Vol. 94, č. 19, 2016

FRUMAROVÁ, K.: Narovnání - nově zavedený institut tzv. odklonu do řízení o přestupku. In Správní právo, roč. 50, č. 7 - 8, 2017, s. 465.07. IVOR, J.: Základné zásady trestného konania. In IVOR, J., POLÁK, P., ZÁHORA, J.: Trestné právo procesné 1. Bratislava: Wolters Kluwer, 2017

JAKAB, R.: Uplatnenie restoratívnych prístupov v konaní o priestupku. In ROMŽA, S., FERENČíKOVÁ, S., MICHAL'OV, L., TÓTHOVÁ, V. (eds.) 2. Košické dni trestného práva : poškodený trestným činom a obete trestných činov, možnosti posilňovania ich procesných oprávnení : zborník vedeckých príspevkov z Interdisciplinárnej celoštátnej vedeckej konferencie s medzinárodnou účastou. Košice: Univerzita Pavla Jozefa Šafárika v Košiciach, 2018

JAKAB, R.: Právo poškodeného priestupkom na spravodlivý proces. In Štát a právo. Roč. 7, č. 1, 2020

KANÁRIK, I.: Výklad práva. In BRÖSTL, A. a kol.: Teória práva. Plzeň: Aleš Čeněk, 2013

KNAPP, V.: Teorie práva. Praha : C. H. Beck, 1995

KOŠIČIAROVÁ, S.: Povinnost' správneho súdu aplikovat' trestnoprávne zásady vo veciach správneho trestania. In Justičná revue. Roč. 68 , č. 8 - 9, 2016

MATES, P.: Analogie ve správním právu. In Správní právo, roč. 44, č. 6, 2011, s. 349.14. MATES, P.: Analogie ve správním právu, kdy ano a kdy ne. In Správní právo, roč. 47, č. 1 - 2, 2014

MICHAL'OV, L.: Podmienky ukladania alternatívnych trestov z pohl'adu de lege ferenda. In ROMŽA, S., FERENČÍKOVÁ, S., MICHALOV, L. (eds.) IV. Košické dni trestného práva. Privatizácia výkonu trestu odňatia slobody, sci-fi alebo jediná možnost? Zborník vedeckých prác. Košice: Univerzita Pavla Jozefa Šafárika v Košiciach, 2020

MILUČKÝ, J.: Vybrané otázky administratívneho sankcionovania v praxi. In Správní právo, roč. 52, č. 7, 2019

MOLITORIS, P.: Priestupkové konanie. In JAKAB, R., MOLITORIS, P.: Správne právo procesné. Košice : Univerzita Pavla Jozefa Šafárika v Košiciach, 2018

MOLITORIS, P.: Vzt’ah medzi zákonnost'ou a prípustnost'ou dôkazov vo veciach správneho trestania. In: STUDIA IURIDICA Cassoviensia. Roč. 6, 2018, č. 1, 2018

MUSIL, J.: Teoretická a ústavní východiská správního trestání. In Acta Universitatis Carolinae Iuridica 1/2010. O veřejné správě, č. 1,2010

PALKOVIČ, J.: Komentár k ustanoveniu § 2 Trestného poriadku. In ČENTÉŠ, J. a kol.: Trestný poriadok. Vel'ký komentár. Bratislava : Eurokódex, 2014

ROMŽA, S.: Aktívna účast' poškodeného na procesných úkonoch prípravného konania ako prostriedok efektívneho uplatňovania jednotlivých foriem restoratívnej justície. In STRÉMY, T. (ed.) Restoratívna justícia a alternatívne tresty v aplikačnej praxi. Zborník z medzinárodnej vedeckej konferencie. Trnava : Leges, 2015 
ROMŽA, S.: Konkurencia procesných alternatív. In STRÉMY, T. (ed.) Restoratívna justícia a systém alternatívnych trestov. Zborník príspevkov z medzinárodnej vedeckej konferencie. Trnava : Leges, 2017

ROMŽA, S.: Limity procesného statusu poškodeného v prípravnom konaní. In: Olomoucké právnické dny 2018: sekce trestního práva. Sborník z 12. ročníku mezinárodní vědecké konference. Olomouc : Iuridicum Olomoucense, 2018

SEMAN, T.: Verejná správa v správnom súdnictve. Košice : Univerzita Pavla Jozefa Šafárika v Košiciach, 2016

SEMAN, T.: Vplyv ustanovení o správnej žalobe vo veciach správneho trestania $(\S 194-\S 198$ zákona č. 162/2015 Z. z. Správny súdny poriadok, v znení neskorších predpisov) na administratívne konanie vo veciach správneho trestania. In FRUMAROVÁ, K (ed.) Správní soudnictví - 15 let existence soudního rádu správního vs. prvotní zkušenosti s aplikací nového správneho súdneho poriadku. Olomouc : Iuridicum Olomoucense, 2018

SPIŠIAKOVÁ, H.: Zákon o priestupkoch. Komentár. Bratislava : Wolters Kluwer, 2015

SREBALOVÁ, M.: Limity aplikácie zásad správneho trestania v praxi. In Přestupky a ř́zení o nich z pohledu teorie a praxe. Praha : Policejní akademie ČR, 2014

ŠTRKOLEC, M.: Postavenie poškodeného pri realizácii vybraných odklonov v trestnom konaní. In 2. Košické dni trestného práva: poškodený trestným činom a obete trestných činov, možnosti posilňovania ich procesných oprávnení. Zborník vedeckých príspevkov z interdisciplinárnej celoštátnej vedeckej konferencie s medzinárodnou účast’ou. Košice : Univerzita Pavla Jozefa Šafárika v Košiciach, 2018 